\title{
Treatment of central serous chorioretinopathy with beta-blocker metipranolol
}

\author{
Oldrich Chrapeka, Barbora Jirkovaa ${ }^{a}$ Vít Kandrnal' ${ }^{b}$ Jiri Rehaka, Martin Sin ${ }^{\mathrm{a}}$
}

\begin{abstract}
Aim. The purpose of this study was to evaluate the effect of the systemically administered betablocker metipranolol on the course of central serous chorioretinopathy (CSC).

Methods. A prospective double-blind study involving 48 patients with a first attack of CSC not exceeding two weeks and who agreed to the follow-up ophthalmology examinations every week. The group was divided into a metipranolol group $(n=23)$, receiving $10 \mathrm{mg}$ of drug twice per day and a placebo group $(n=25)$. The outcome measure was time in weeks from drug intervention (metipranolol vs. placebo) to reattachment of macula neuroepithelium.

Results. There was no statistically significant difference in duration of CSC in patients who used metipranolol and those who used placebo $(P=0.341)$.

Conclusions. In a prospective double-blind study, we found no effect of the betablocker metipranolol on the duration of central serous chorioretinopathy.
\end{abstract}

Key words: betablocker, central serous chorioretinopathy, metipranolol

Received: November 26, 2012; Accepted: February 26, 2013; Available online: March 21, 2013

http://dx.doi.org/10.5507/bp.2013.015

${ }^{a}$ Department of Ophthalmology, University Hospital Olomouc and Faculty of Medicine and Dentistry, Palacky University Olomouc, Czech Republic

'Institute of Biostatistics and Analyses, Faculty of Medicine, Masaryk University, Brno

Corresponding author: Martin Sin, e-mail:sin.martin@seznam.cz

\section{INTRODUCTION}

Central serous chorioretinopathy (CSC) is a clinical entity known since 1866, when it was first described by Albert von Graefe under the name central recurrent retinitis ${ }^{1}$. CSC occurs most frequently between the ages of 20-50 and affects the eyes of persons who are otherwise healthy. It is manifested only in one eye, impairment of both eyes is very rare and almost never simultaneously. It is more frequent in males than females: reported ratio ranges from 3:1 to 9:1 ( ref. $^{2,3}$ ). Older patients with CSC have an average lower visual acuity, more frequent diffuse retinal pigment epitheliopathy, bilateral impairment and secondary choroidal neovascularisation ${ }^{4,5}$. Efficient conservative treatment for CSC is still subject to investigation as are its putative causes. Some authors claim that it may be caused by systemic and retrobulbar administration of corticosteroids $^{6,7}$. Avci et al and Fabianova et al described positive experience with the betablockers, metipranolol and metoprolol. These proved useful in all patients with acute attack of CSC reducing the duration of serous detachment of macular neuroepithelium for a period shorter than 10 weeks $^{8,9}$.

We decided to test these findings using one of the betablockers on acute CSC.

\section{MATERIALS AND METHODS}

From 2005-2010, we evaluated in a prospective double-blind placebo controlled study, the effect of the nonselective betablocker metipranolol administered in a dose of $10 \mathrm{mg}$ twice a day on the course of acute attack of CSC.

Metipranolol was administered to 23 patients, 19 males and 4 females, average age 44 years. The right eye was affected 14 times, and the left 9 times. Placebo was administered to 25 patients, 17 males and 8 females, average age 44 years. The right eye was affected 12 times, and the left 13 times. The inclusion criteria for the study group were only patients with a first attack of CSC, no eye operation or laser photocoagulation performed in the past, no trauma to the eyes, no cloudy eye media detected or exudation to the vitreous body, no occlusive vessel disease, hypertensive or diabetic retinopathy, vitreoretinal traction, melanoma type lesions, hemangioma or other unusual retinal or choroideal abnormality. Noncooperative patients and patients with allergy to fluorescein were excluded. There were also no patients included in the group with leakage greater than 250 micrometres in diameter detected during the early phase of fluorescein angiography in order to exclude a possible subretinal neovascular membrane. In all patients there was CSC of recent onset and a history of complaints no longer than two weeks. We evaluated the visual acuity on the Early Treatment Diabetic Retinopathy Study (ETDRS) visual acuity chart. Diagnosis was established on the basis of biomicroscopic examination with macular oedema observation, fluorescein angiography with the finding of the point of leakage (Topcon digital system) and optical coherence tomography (OCT) demonstraiting the detachment of the neuroepithelium of the macula (OCT3 Stratus). Using computer perimetry we demonstrated decreased retinal sensitivity of the macula in the eye with the acute CSC 
compared with the other unaffected eye. All patients were examined by their own general practitioner. The group included only those patients with no contraindications to systemic administration of betablockers demonstrated and who agreed to the follow-up examinations of the eye every week. The outcome measure was chosen as time in weeks since drug intervention/placebo to reattachment of macula neuroepithelium. The reattachment of the neuroepithelium of the macula was confirmed with OCT. As a criterion of therapeutic success we selected reattachment of neuroepithelium at the latest, within 16 weeks of intervention. If within this time frame there was no reattachment of macula neuroepithelium, it was left to the discretion of the study doctor, whether the patient would be treated with laser photocoagulation or if he/she would continue with conservative therapy.

The study drug/placebo were prepared in the hospital pharmacy. These were visibly identical capsules. One type of capsule in a vial with a purple strip contained crushed tablets of metipranolol in a dose of $10 \mathrm{mg}$ in one capsule. The second type of capsule in a vial with a green strip did not contain the active ingredient. Patients in both groups took 1 capsule in the morning and 1 in the evening. Only one physician in the research team kept records on the content of the vial and what individual patients used. $\mathrm{He} /$ she did not contribute during the study to the entry, interim or final examinations and only at the conclusion of the trial, disclosed the treatment option of each patient.

For statistical comparison we used the Mann-Whitney $\mathrm{U}$ test and the significance level was 0.05 .

\section{RESULTS}

In 23 patients of metipranolol group the average entry visual acuity was 78 ETDRS letters and the average entry macular thickness was 346 micrometers. The average duration of the neuroepithelium detachment in this group was 13 weeks. The shortest period of neuroepithelium detachment was 1 week long, the longest period of neuroepithelium detachment was 42 weeks long. In the metipranolol group, 16 patients achieved reattachment of macula neuroepithelium within 16 weeks of intervention (successful) and 7 did not (unsuccessful). No laser photocoagulation was done on any of the unsuccessfully treated patients. In the moment of neuroepithelium reattachment the average final visual acuity was 84 ETDRS letters and the average final macular thickness was 178 micrometers. The duration of metipranolol administration in weeks to reattachment of neuroepithelium for each patient is shown (Fig. 1).

In 25 patients of the placebo group the average entry visual acuity was 76 ETDRS letters and the average entry macular thickness was 338 micrometers. The average duration of the neuroepithelium detachment in this group was 12 weeks. The shortest period of neuroepithelium detachment was 4 weeks long. The longest period of neuroepithelium detachment was 48 weeks long. In the placebo group, 21 patients achieved reattachment of macula neuroepithelium within 16 weeks (successful) and
4 did not (unsuccessful). No laser photocoagulation was performed on any of the unsuccessful cases. In the moment of neuroepithelium reattachment the average final visual acuity was 83 ETDRS letters and the average final macular thickness was 182 micrometers. The duration of placebo administration in weeks to reattachment of neuroepithelium for each patient is shown (Fig. 2).

The Mann-Whitney test showed no statistically significant difference between the duration of therapy in patients taking metipranolol and in those who took placebo $(P=0.341)$. It was therefore not possible to demonstrate that betablocker metipranolol administered in a dose of $10 \mathrm{mg}$ twice per day statistically significantly shortened the duration of complaints and accelerated reattachment of macula neuroepithelium in patients with acute attack of CSC.

\section{DISCUSSION}

Use of betablockers in the treatment of CSC comes from past research. In 1966 Potts reported that the flow in precapillar arteriols in the submacular choroidea is controlled by ciliary nerves and he hypothesised that CSC may be due to faulty neural control of submacular choroidal perfusion ${ }^{10}$. Since then various authors have re-

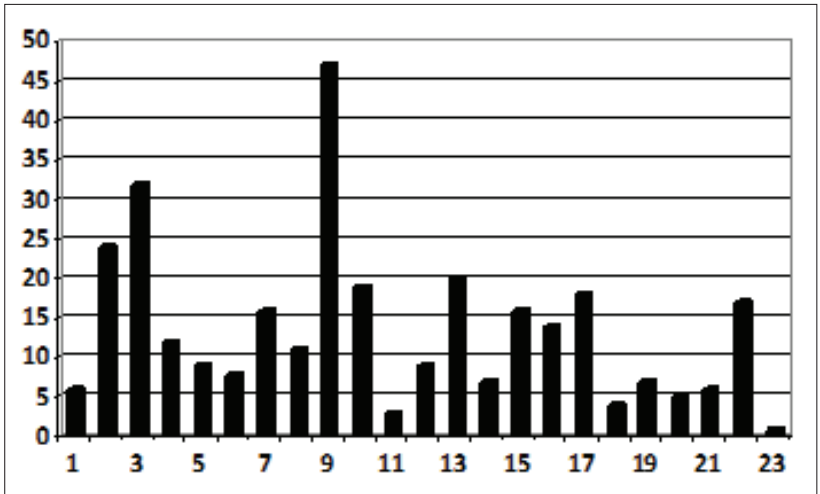

Fig. 1. Duration of therapy of 23 patients during the administration of metipranolol 2 times $10 \mathrm{mg}$ per day expressed in weeks.

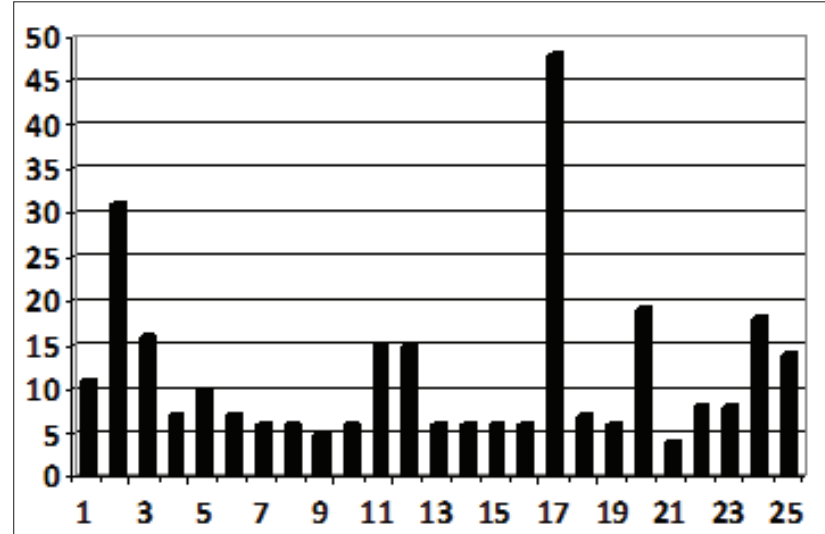

Fig. 2. Duration of therapy in 25 patients during the administration of placebo expressed in weeks. 
ported an image of CSC on the retina of experimental animals after intravenous administration of epinephrine ${ }^{11-13}$. Yannuzi demonstrated that among his patients with CSC there were more frequently type A personalities, who typically have higher levels of epinephrine, norepinephrine and cortisol in blood plasma along with higher activity of the adrenergic system ${ }^{14}$. One explanation for CSC pathogenesis is that stress induces adrenergic dysregulation of the choroidal circulation. Reduction of arterial filling in circulation regions such as choroidea results in activation of leukocytes which accumulate with subsequent leukocyte plugs followed by capillary and venous congestion. Activation of proteolytic enzymes and increased exudation of fluid from the capillaries of choroideal lobules under the retinal pigment epithelium with its subsequent detachment follows. Detachment means a mechanical stress for cells of the retinal pigment epithelium. Their lysosomal enzymes are then activated, which simultaneously with proteolytic and leukocyte enzymes create a defect in retinal pigment epithelium, through which flows fluid under the neurosensoric layer of the retina with the development of clinical manifestation of the disease ${ }^{2}$. In 1984 Koh and Chader showed experimentally the presence of beta-adrenergic receptors in cells of the retinal pigment epithelium in chicken ${ }^{15}$. Spitznas et al. stated that excessive adrenergic stimulation of beta-adrenergic receptors of cells of the retinal pigment epithelium results in elevation of intracelullar concentration of cAMP with subsequent dysfunction of the ion pump in the cell membrane of the retinal pigment epithelium. The result is influx of fluid under the retinal neuroepithelium ${ }^{16}$. Use of betablockers in the treatment of CSC is based on the fact that betablockers reduce release of catecholamines from the CNS and in this way attenuate activity of the adrenergic system. Blockage of beta-adrenergic receptors in the cells of the retinal pigment epithelium contributes to stabilisation of transport events in these cell membranes.

Avci, Deutman was the first to report the use of the beta-one selective blocker metoprolol in a dose of $50 \mathrm{mg}$ twice per day in the treatment of an acute attack of CSC. The treatment was used in seven eyes. The results showed that onset of the remission of CSC took place in all patients at the latest, within ten weeks of commencing treatment ${ }^{8}$. Fabianova et al. used the beta non-selective blocker metipranolol in a daily dose of $10 \mathrm{mg}$ twice a day in 21 patients; in 30 patients they administered the beta-one selective blocker metoprolol in a dose of $50 \mathrm{mg}$ twice per day. In all patients there was remission of CSC at the latest, within 6 weeks of commencing therapy ${ }^{9}$.

In 2002 we published our experience with the treatment of CSC using the non-selective betablocker metipranolol in a dose of $5 \mathrm{mg}$ twice per day. We treated 13 patients with acute attack of CSC. We reported that in 11 patients $(84.6 \%)$ there was reattachment of neuroepithelium of the macula within four months of therapy; on average in 8.8 weeks. In two patients $(15.4 \%)$ this conservative therapy did not result in reattachment of macula neuroepithelium even after 4 months of treatment. In one such unsuccessfully treated patient, we proceeded to direct laser photocoagulation of the leaking point, after which reattachment occurred in 7 weeks; in the second eye the leakage point was not treatable with laser due to its localisation near the centre of foveola and therefore we continued with conservative therapy. We increased the dose of metipranolol to $10 \mathrm{mg}$ twice per day and reattachment occurred after 10 weeks of therapy ${ }^{17}$. A dose of metipranolol $10 \mathrm{mg}$ twice a day has been described in the literature as successful ${ }^{9}$. For this reason, we decided to confirm the effect of metipranolol in a daily dose of $10 \mathrm{mg}$ twice per day in the treatment of CSC in a prospective double-blind study. From the results of the present study in a group of patients who used metipranolol in a dose of $10 \mathrm{mg}$ twice a day we demonstrated reattachment of macula neuroepithelium in 16/23 patients within 16 weeks of therapy and the treatment was evaluated as effective; treatment failed in $7 / 23$ patients. In the placebo group reattachment of the macula neuroepithelium occurred in $21 / 25$ patients within 16 weeks and was counted as successful. Treatment failed in 4 patients using the 16 week criterion. The average duration of the neuroepithelium detachment in the metipranolol/placebo group was $13 / 12$ weeks. One possible explanation for these results is that the cause of serous detachment of the macula neuroepithelium in patients with CSC is complex, involving mechanisms not understood to date and a dysfunction which cannot be treated by the betablocker metipranolol.

\section{CONCLUSION}

In a prospective double-blind study we demonstrated that the betablocker metipranolol administered in a dose of $10 \mathrm{mg}$ twice a day does not statistically significantly shorten the duration of serous detachment of neuroepithelium of the macula in patients with an acute attack of CSC.

\section{ACKNOWLEDGEMENT}

The study was performed with informed consent and following all the guidelines for experimental investigations required by the Ethic Committee of University Hospital Olomouc and Faculty of Medicine and Dentistry of Palacky University Olomouc to which all authors are affiliated.

Authorship contributions: OC: study design; OC, BJ: manuscript writing; OC, JR, MS: data collection; OC, JR, MS: literature search; VK: statistical analysis; JR: final approval.

Conflict of interest statement: The authors stated that there are no conflicts of interest regarding the publication of this article.

\section{REFERENCES}

1. Von Graefe A. Über centrale recidivierende Retinitis. Graefes Arch Clin Exp Ophthalmol 1866;12:211-5. 
2. Fabianova J, Porubska M, Cepilova Z. Centralna serozna chorioretinopatia- novy model etiopatogenezy. Cesk Slov Oftalmol 1998;54:405-88.

3. Kondrova J. Centralni serozni chorioretinopatie. Cesk Slov Oftalmol 1995;51:304-9.

4. Romani A, Bartolomei MP, Puccioni M, Malfatti P. Alterazione del senzo cromatico consegunte a corioretinopatia sierosa centrale. Ann Oftal Clin Oculist 1987;113:759-63.

5. Brancato R, Bandello F. Central serous retinopathy (atypical forms). Bull Soc Belge Ophtalmol 1991;240:119-31.

6. Harada T, Harada K. Six cases of central serous choroidopathy induced by systemic cortocosteroid therapy. Doc Ophthalmol 1985;60:37-44.

7. Bandello F, Incorvaia C, Rosa N, Parmeggiani F, Costagliola C, Sebastini A. Bilateral central serous chorioretinopathy in a patient treated with systemic cortico-steroids for non-Hodgkin lymphoma. Eur J Ophthalmol 2002;12:123-6.

8. Avci R, Deutman AF. Die Behandlung der zentralen serösen Choroidopathie mit dem Betarezeptorenblocker Metoprolol. Klin Monbl Augenheilkd 1993;202:199-205.

9. Fabianova J, Porubska M, Cepilova Z. Centralna serozna chorioretinopatia- liecba betablokatormi. Cesk Slov Oftalmol 1998;54:401-4.
10. Potts AM. An hypothesis on macular disease. Trans Am Acad Ophthalmol Otolaryngol 1966;70:1058-62.

11. Miki T, Sunada I, Hagaki T. Studies on chorioretinitis induced in rabits by stress (Repeated administration of epinefrine). Acta Soc Ophthalmol Jpn 1972;76:1045-57.

12. Nagayoski K. Experimental study of chorioretinopathy by intravenous injection of adrenaline. Acta Soc Ophthalmol Jpn 1971;75:1720-7.

13. Yasuzumi T, Miki, T, Sugimoto K. Electron microscopic studies of epinefrine choroiditis in rabbits. I. pigment epithelium and Bruch's membrane in the healed stage. Acta Soc Ophthalmol Jpn 1974;78:588-98.

14. Yannuzzi LA. Type- A behaviour and central serous chorioretinopathy. Retina 1987;7:111-30

15. Koh SWM, Chader GJ. Retinal pigment epithelium in culture demostrates a distinct beta- adrenergic receptor. Exp Eye Res 1984;38:713.

16. Spitznas M. Pathogenesis of central serous retinopathy: a new working hypothesis. Graefes Arch Clin Exp Ophthalmol 1986;224:321-4

17. Chrapek O, Spackova K, Rehak J. Lecba centralni serozni chorioretinopatie betablokatory. Cesk Slov Oftalmol 2002;58:382-6. 